\title{
自動運転使用時におけるドライバ行動の観察と考察
}

\author{
貴答 竣亮 ${ }^{a}$ 荒川 俊也 , $^{*}$
}

\section{Observation and Consideration of Driver Behavior on Autonomous Driving}

\author{
Shunsuke Kitou ${ }^{\mathrm{a}}$, Toshiya Arakawa ${ }^{\mathrm{b}, *}$
}

(Received May 20, 2020; revised July 22, 2020; accepted July 28, 2020)

\begin{abstract}
In the revised road traffic law, drivers are allowed to engage in non-driving-related behaviors, such as reading books and operating smartphones, while using the Society of Automotive Engineers (SAE) level 3 autonomous driving. However, previous research shows that drivers over-rely on autonomous driving. The safety of SAE level 3 autonomous driving will be in question if it allows drivers behaviors unrelated to driving. Therefore, we observed drivers' behavior on autonomous driving using a driving simulator and consider the tendency of behavior. The results show that most drivers become sleepy with time and operate their smartphones because they become bored during autonomous driving.
\end{abstract}

キーワード：自動運転，ドライバ行動，ドライビングシミュレータ

Keywords : autonomous driving, driver behavior, driving simulator.

\section{1.はじめに}

本論は，自動運転使用時におけるドライバ行動の観察 と考察について述べた上で, 自動運転レベル 3 のあり方 について述べたものである。

我が国を取り巻く環境として，少子高齢化や都市部の 人口集中をはじめとした社会構造の変化を背景に，道路 交通を巡る様々な社会的課題の深刻化が眯念されている。 例えば，高齢者が原因の交通事故割合の増加や，それに 伴う地方交通事業者ならびに地方公共団体の財政逼迫， 運転者不足などの複合的要因が相まって, 地域公共交通 ネットワークの維持の困難などによる交通空白地帯の拡 大, 高齢者に代表される移動弱者の移動確保などである (1)。他方, 三大都市圈を中心とした都市部では, 経済活動 や人口の更なる集中化やインバウンド需要の増加を背景 として交通渋滞や混雑が発生すれば, 経済損失や地球温

* Corresponding author. E-mail: arakawa-toshiya@aut.ac.jp

a 日産自動車株式会社（前：愛知工科大学)

干 220-8623 神奈川県横浜市神奈川区宝町 2 番地

Nissan Motor Co., Ltd.

2, Takara-cho, Kanagawa-ku, Yokohama-shi, Kanagawa, Japan 220-8623

b 愛知工科大学

干 443-0047 愛知県蒲郡市西迫町馬乗 50-2

Aichi University of technology

50-2, Manori, Nishihasama-cho, Gamagori-shi, Aichi, Japan 443 0047
暖化の要因となることが懸念されている(2)。加えて，物 流では, e-コマースの更なる拡大等による物流需要の拡 大が見込まれている中, 職業ドライバとして中高年層運 転者に依存している現状, 物流の担い手不足も課題とし て挙げられている(1)。このような状況の中，自動運転へ の期待が高まっている。上記以外にも，自動運転のメリ ットとして,「人間のドライバよりも上手に賢く運転でき る」ことも挙げられている(3)。

自動運転には，自動化されている機能によって段階毎 にレベルが存在する。表 1 に，レベル毎に備えている機 能を示す(4)。なお, 表 1 における自動運転レベルの定義 は, SAE International J3016 の定義(5)である。自動運転レ ベル 0 からレベル 2 までは, 安全運転に係る監視や対応 の主体がドライバであるが，レベル 3 からレベル 5 まで は，監視や対応の主体がシステムである，という点で大 きな違いがある。レベル 1 または 2 の自動運転化システ ム，もしくはレベル 3 の自動運転システムの性能が向上 すればするほど，ドライバの運転機会が減少することに よる運転技能の低下だけでなく，システムに対する過信 が生じることで，システムの機能失陥時にドライバが対 応できない状況が起こり得る(6)。一方，2020 年 4 月 1 日 に改正道路交通法が施行され，自動運転に関しては，道 路交通法第 71 条 4 の 2 第 2 項において自動運行システ ムが故障したり，システムの条件に合わない状況となっ 
Table 1. Level of autonomous driving(3).

\begin{tabular}{|c|c|c|}
\hline \multirow{5}{*}{$\begin{array}{l}\text { ドライバに } \\
\text { よる監視 }\end{array}$} & レベル 0 & 運転支援なし \\
\hline & & 運転支援 \\
\hline & レベル 1 & システムが前後・左右のいず \\
\hline & & れかの車両制御を実施 \\
\hline & レベル 2 & $\begin{array}{l}\text { 特定条件下での運転支援機 } \\
\text { 能（レベル } 1 \text { の組み合わせ） }\end{array}$ \\
\hline \multirow{3}{*}{$\begin{array}{l}\text { システムに } \\
\text { よる監視 }\end{array}$} & レベル 3 & 条件付き自動運転 \\
\hline & レベル 4 & $\begin{array}{l}\text { 特定条件下における完全自 } \\
\text { 動運転 }\end{array}$ \\
\hline & レベル 5 & 完全自動運転 \\
\hline
\end{tabular}

た場合，「直ちにそのことを認知して確実に車の操作をで きる状態にある」という条件付きで，例えば，運行中の スマートフォン (以下スマホ) ・携帯電話操作, パソコン 作業, 読書, 食事などを認めるようになったとされてい る(7)。しかし, 先行研究(8,9)で, 自動運転への過信や依存 に起因し, 自動運転からマニュアル運転に移行した際に, 意識の脇見 ${ }^{(10)} に$ 近い状態にあることなどが示されてお り，自動運行システムが故障したり，システムの条件に 合わない状況となった場合，ドライバが「直ちにそのこ とを認知して確実に車の操作をできる状況にある」とは 言い難いことが示唆されている。先行研究(7-9)ではこのこ とについて生体情報の観点から示唆されているが, そも そも, 自動運転中にドライバがどのような行動を取るか, 観察をして䌂めた事例は殆ど見られない。筆者は, その 理由として，これまでの自動運転におけるドライバ状態 に関する研究が, ドライバ行動を制限した状況下で行わ れており，実際の自動運転時に近い状況でドライバ行動 を評価していないためであると考えている。

本論では，ドライビングシミュレータによる自動運転 を模擬した環境下を走行した際に，ドライバがどのよう な行動を取るかについて観察し，その結果に関する考察 を述べる。そして，自動運転中に，ドライバが取る行動 に拘らず，常に「直ちに確実に車の操作をできる状況に ある」か否かを考察する。本論で述べる実験手法は非常 に簡単なものであり，また，ドライバ行動については， 動画を撮影し観察しただけであり，実験協力者も5 名と 少ない。しかし，行動を制限せずに実験を実施した環境 下で，ドライバの行動を記録したという意味では，今後 の自動運転のあり方を考える資料として有益であり，本 論の貢献する所であると考える。

本論の構成は次の通りである。第 2 節では実験環境に ついて説明する。第 3 節では実験結果について述べる。 第 4 節では実験結果に対して考察する。第 5 節はまとめ である。

\section{2. 実験環境}

実験には 5 名の実験協力者 (男子大学生 5 名, 平均年 齢 21.8 歳, 実験協力者 A から E とする) が参加した。な お, 本論では, 実験協力者は 5 名と少ないが, 先行研究 (9)では, 本論より年齢層を広げ,また, 男性のみならず女 性も実験協力者とし, 自動運転に対する過信や依存と生 体情報の傾向について述べており，年齢および性差の影 響は見られなかった。また，本論で述べる実験は，ドラ イバ行動の観察を主体としており，詳細な評価は行って いない。そのため，本論では，少ない人数の実験協力者 であっても，再現性や汎化性の観点で問題ないものと判 断した。実験にはドライビングシミュレータ (DS-nano-, 株式会社アストジェイ (現: 株式会社 $\mathrm{CCN}$ グループ) 製)

（図 1）を用いた。ドライビングシミュレータには実車 のキャビンを設置してある。それぞれの実験協力者には, ドライビングシミュレータ上で模擬した，レベル 2 以上 を想定した自動運転で高速道路を走行するシナリオで 30 分間運転し, 運転時の実験協力者の様子を, ビデオカ メラ（GZ-E325，株式会社 JVC ケンウッド製）で撮影し た。なお，ドライビングシミュレータは，エンジン回転 数に比例した走行音が提示されている。モータとステア リングは直結されており，ステアリングは，ドライビン グシミュレータのメイン PC からの指示を受けた Raspberry pi を介してモータに制御信号が送信され，この 制御信号に併せて動作する。従って，本論で述べる自動 運転のシナリオでは，常に車線中央を走行するようにス テアリングも動作する。シート座面には，重低音を振動 で伝えるボディソニックトランスデューサ（DN-82305, サードウェーブ株式会社製）が備え付けられており，走 行時の振動がドライバに伝達されるようになっている。 本研究はドライビングシミュレータ環境での実験である ため，実車環境との乘離はあるものの，極力，高速道路 走行時の実車環境に近い状況を再現している。ドライビ ングシミュレータ全体の構成を図 2 に示す。

高速道路は次のような形状に設定した。

- 形状 : 直線 + 曲線 (曲線部の最小曲率半径 : 700 [m])

- 車線幅 : $3.5[\mathrm{~m}]$

- 車線数 : 3 車線

- 距離 : $10[\mathrm{~km}]$

この道路について, $10[\mathrm{~km}]$ 走行した時点でスタート地 点に戻してループするように設計し，30[分]走行可能に した。なお，他車両は存在しない。

実験協力者は自動運転中に運転に関係のない行動を行 うことが想定されるが, その行動が, 自動運転への信頼 に起因するものかを調べる必要がある。また, 仮に, 運 転に関係のない行動を行ったとしても，自動運転システ ムが故障したり，システムの条件に合わない状況となっ 


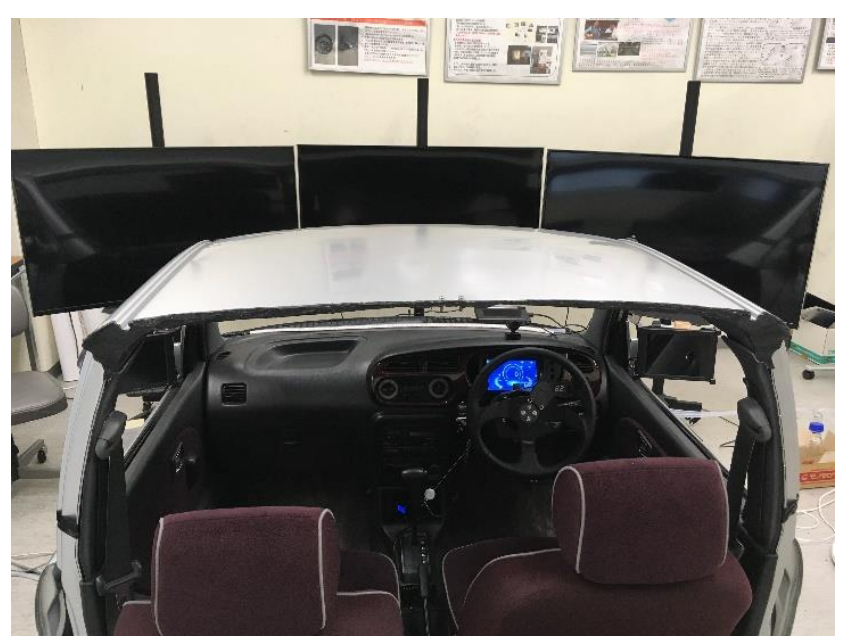

Fig. 1. Driving simulator.

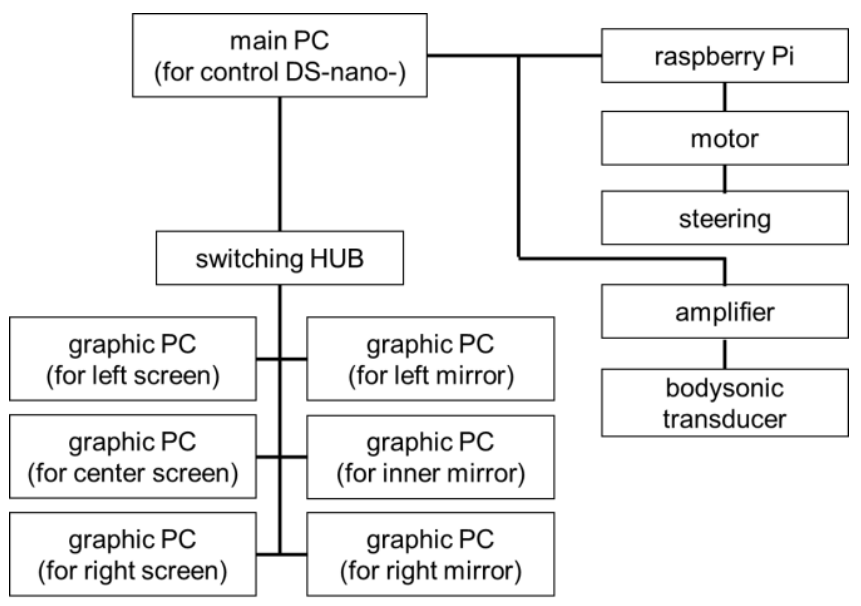

Fig. 2. Block diagram of driving simulator.

た場合，ドライバが「直ちにそのことを認知して確実に 車の操作をできる状況」にあれば問題がない。本論では, 先行研究(11)に基いて, 自動運転時に覚醒度が低下寸るこ とを踏まえる。そのため, 実験協力者には, 眠気と, 自 動運転システムに対する信頼に関して質問した。

それぞれの実験協力者は, 運転中, 3 分毎に, 自身の眠 気と，自動運転システムへの信頼に関する質問を，実験 実施者より行動で受け，それに対して口頭で回答した。 口頭質問は，「いま眠気を感じているか?」「現時点で自 動運転に対して信頼しているか?」という内容であり， 各実験験協力者はこれらの質問に対して 5 点法で回答し た。眠気に関する質問については，1:全く眠くないー3： 少し眠い-5: 非常に眠い，の 5 点法であり，自動運転に 対する信頼に関する質問については， 1 : 全く信頼してい ないー3: どちらでもないー5: 非常に信頼している，の 5 点法とした。なお, 眠気については, 実験開始時にも質 問をした。実験協力者には, 運転開始前に, 自動運転で の運転であり，自身で，ステアリング，アクセル，ブレ 一キの操作は不要であること, 運転中は運転以外の行為
を行っても構わない旨伝えた。運転の時間は 30 分間であ ることも，事前に伝えてある。

なお, 本実験は, 愛知工科大学ヒ卜を対象とする研究 審査の承認を得た上で実施し（30-5 号)，全ての実験協力 者に対して, 書面でのインフォームド・コンセントを得 ている。

\section{3. 実験結果}

\section{1 眠気の変化}

実験協力者 5 名の，口頭での質問に対する回答に基づ いた眠気の変化を, 図 3 に示す。なお, 図 3 において, 眠気が変化する場合，3分毎の回答であるため，実際に はステップ的な変化であるが，徐々に眠気が増加してい るということを考え, 線形補間して示している。また, 実験開始時の眠気は 0 [分]の箇所に示した。図 3 より, 運転開始時に眠気を感じていた実験協力者も, 眠気を感 じていなかった実験協力者も混在しているものの, 運転 終了時には, 眠気が， 5 段階中 3 もしく 4 に推移して いることがわかる。運転開始時から眠気を感じている（3 以上とする）の実験協力者は, 眠気がほぼ維持されてお り, 運転開始時に眠気を感じていない（3未満とする）実 験協力者は, 時間経過と共に, 徐々に増加する傾向にあ る。

\section{2 依存度の変化}

実験協力者 5 名の, 口頭での質問に対する回答に基づ いた依存度の変化を, 図 3 に示す。なお, 眠気の変化と 同様に, 図 3 において, 依存度が変化する場合, 3 分毎 の回答であるため, 実際にはステップ的な変化であるが, 徐々に依存度が増加しているということを考え, 線形補 間して示している。

依存度については,一貫した傾向は見受けられないが， 基本的には，高いレベルを維持している。また，実験協 力者 Aと D のように, 時間経過に伴い, 徐々に増加する 実験協力者も存在する。

\section{3 ドライバ行動について}

運転開始時から 30 分経過までの, ドライバ行動につい て, 撮影したビデオカメラの動画像を基に目視観察し, 表 2 にまとめた。表 2 より，5名の実験協力者のうち 4 名に, 運転中にスマートフォンを操作する行為が見られ た。例として, 図 4 に, 実験協力者 $\mathrm{A}$ が, 運転中にスマ ホを操作している様子を示す。

全ての実験協力者について, スマホを操作する行為が 見られた時間帯を, 図 3 中にオレンジ色の網掛けで示し ている。運転時間を 30 分と事前に知らせていたことで, 「早く終わらないであろうか」という気持ちに起因して いるのか，運転終了前の時間のスマホ操作が目立ってい る。表 3 に, 運転開始時から運転終了時まで, 10 [分]毎 に, 動画観察に基づいて, スマホを操作している時間の 

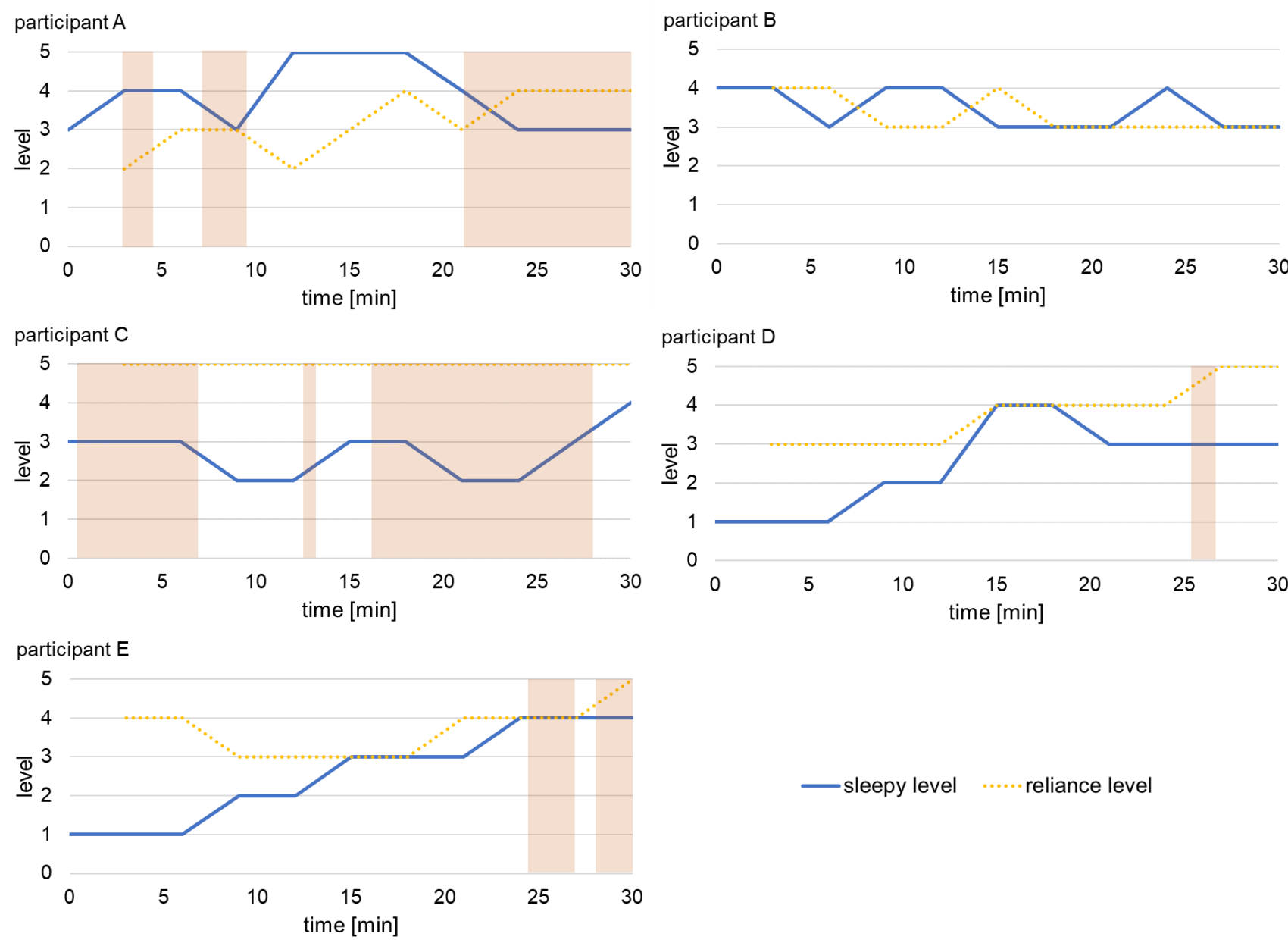

Fig. 3. Transition of sleepy level and reliance level of each participants. Orange-colored areas mean the timing that participants texting a smartphone.

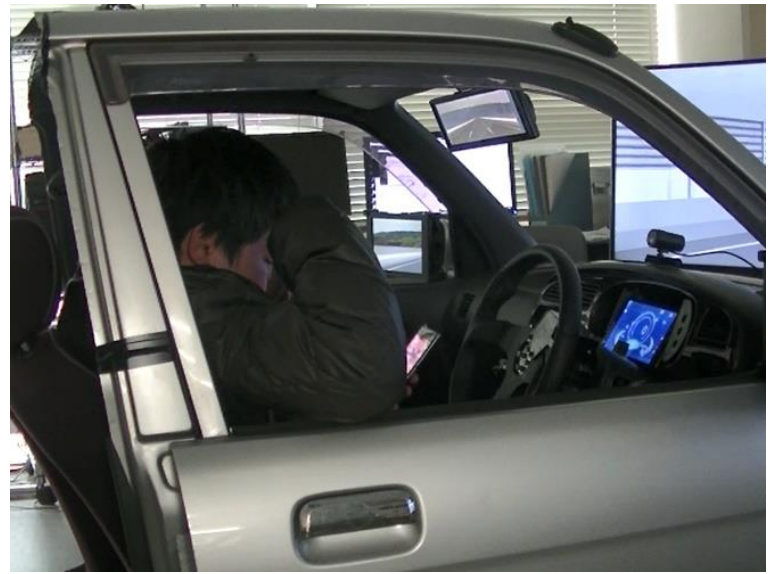

Fig. 4. Situation of operating smart phone on driving.

\section{割合を示す。}

表 3より，20-30[分]におけるスマホの操作が多いこと が目立っていることが示唆される。なお，一要因分散分 析の結果，スマホの操作の割合に有意差は見られなかっ た $(\mathrm{F}(2,12)=1.831, \mathrm{p}>0.05)$ 。そのため,ここで述べたこと はあくまで傾向として捉えられるに過ぎない。
Table 3. Operating smartphone percentage of each participants.

\begin{tabular}{|c|c|c|c|c|c|}
\hline & A & B & C & D & E \\
\hline $0-10[\mathrm{~min}]$ & 41.67 & 0 & 63.33 & 0 & 0 \\
\hline $10-20[\mathrm{~min}]$ & 0 & 0 & 44.83 & 0 & 0 \\
\hline $20-30[\mathrm{~min}]$ & 90.00 & 0 & 80.00 & 13.33 & 45.00 \\
\hline
\end{tabular}

\section{4. 考察}

5 名中 4 名の実験協力者に，自動運転中にスマホを操 作する様子が見られた。ドライビングシミュレータ環境 下であるが，自動運転に対する，過信や依存に起因した 行動であると考えられる。この 4 名が，スマホを操作し ているタイミングについて調べてみると, 殆どの場合, 眠気が 3 (やや眠い) 以上を示している状況下であるこ とがわかる。自動運転が退屈で, やることが無いために, 時間潰しとしてスマホを操作しているようであった。ま た，同時に，眠気の増加（覚醒度の低下）も見られた。 自動運転が退屈であるということや, 自動運転中に覚醒 度が低下寸るということについては, 先行研究(9,11-13)で 
Table 2. Each participant's behavior during autonomous driving.

\begin{tabular}{|c|c|c|}
\hline No. & Time & Behavior \\
\hline \multirow[t]{6}{*}{ A } & $2 ’ 56 ”$ & ズボンからスマホを取り出し, 触る \\
\hline & 4'36”' & スマホをしまい, 右肘をドアに掛ける \\
\hline & 7’00”' & 再びズボンからスマホを取り出し, 触る \\
\hline & $12 ’ 10 ”$ & あくびをする \\
\hline & $15 ’ 25^{\prime \prime}$ & 暇すぎて眠いと独り言を言う \\
\hline & $21^{\prime} 00 ”$ & スマホを取り出してずっと運転する \\
\hline \multirow[t]{3}{*}{$\mathrm{B}$} & $12 ’ 30 ”$ & 眠そうに目をこする \\
\hline & $18 ’ 20 "$ & 首を回しながら，体を一時的にずらす \\
\hline & $25,12 "$ & 腕を右から左に組み直す \\
\hline \multirow[t]{10}{*}{$\mathrm{C}$} & $0 ` 30 ”$ & スマホを触る \\
\hline & 6’53” & スマホを隣の座席に置き, 前方を見る \\
\hline & $12 ’ 31 "$ & スマホを取り出し, 触る \\
\hline & $13^{\prime} 10^{\prime \prime}$ & スマホを置き, 前方を見る \\
\hline & $16^{\prime} 10^{\prime \prime}$ & スマホを取り出し, 触る \\
\hline & $188^{\prime} 40^{\prime \prime}$ & 右手でスマホを触っていたが両手で触る \\
\hline & $21 ' 40 ”$ & 両手から右手でスマホを触り直す \\
\hline & $24^{\prime} 32^{\prime \prime}$ & あくびをした後，すぐスマホを触り直す \\
\hline & $26 ’ 26^{\prime \prime}$ & 再びスマホを両手で持ち直す \\
\hline & $28^{\prime} 00^{\prime \prime}$ & スマホを置き, 両腕を組む \\
\hline \multirow[t]{6}{*}{$\mathrm{D}$} & 4’30” & まばたきを繰り返す \\
\hline & 9’32” & あくびをする \\
\hline & $18^{\prime} 13^{\prime \prime}$ & あくびをする \\
\hline & $18 ’ 27 ”$ & 眠そうに目をこする \\
\hline & $25^{\prime} 20^{\prime \prime}$ & ズボンからスマホを取り出し, 触る \\
\hline & $26^{\prime} 40^{\prime \prime}$ & スマホをしまう \\
\hline \multirow[t]{3}{*}{$\mathrm{E}$} & $24 ’ 30 "$ & ズボンからスマホを取り出し, 触る \\
\hline & $26^{\prime} 26^{\prime \prime}$ & あくびをする \\
\hline & $28^{\prime} 00 "$ & ズボンからスマホを取り出し, 触る \\
\hline
\end{tabular}

も示されており, 今回の結果はこれらの先行研究の結果 を追認していると言える。

全ての実験協力者の行動記録より, 口頭質問の際にス マホを操作していた頻度を, 眠気と, 自動運転への依存 度のそれぞれについて纏めた。眠気については図 5 に, 自動運転への依存度については図 6 に示す。図 5 より, 眠気が強くなるとスマホ操作頻度が増え, また, 図 6 よ り，自動運転に依存していると感じるとスマホ操作頻度 が増えていることがわかる。

実際に, クルマが完全自動運転になった場合, 若者は, 娛楽を楽しみたいという調査結果(14)がある。実車とシミ ユレータという環境の違いはあるが, 本論の実験で見ら れたスマホ操作はこのことを示唆している。しかし，同 時に, 図 3 より, スマホ使用時に強い眠気を感じている

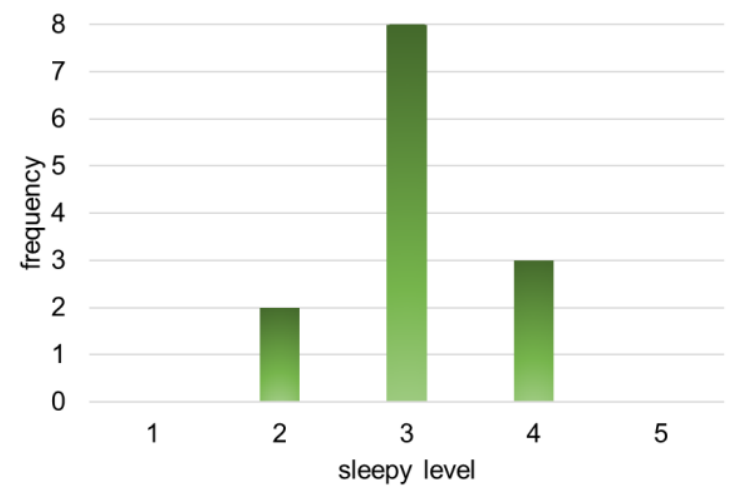

Fig. 5. Frequency of operating smart phone on sleepy.

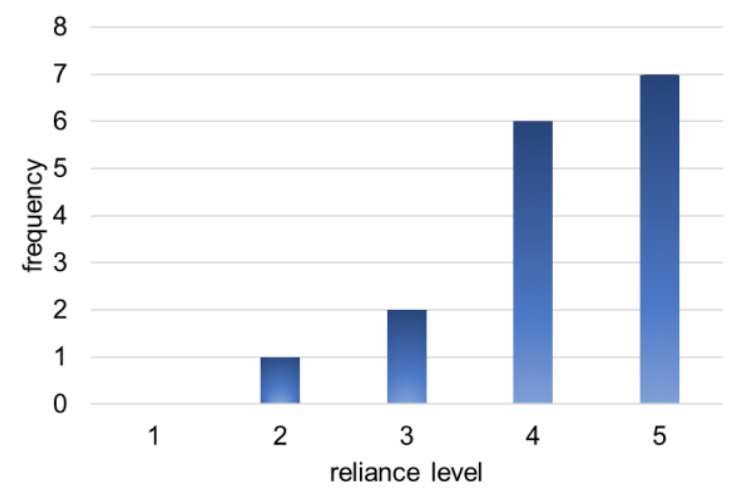

Fig. 6. Frequency of operating smartphone when relying on automated driving.

状況が多い。仮にスマホを使用していたとしても，ドラ イバが「直ちにそのことを認知して確実に車の操作をで きる状況」であれば，自動運転時のスマホ操作は問題は ないと考えられる。しかし，本論で得られた結果を踏ま えて考察すると, 自動運行システムが故障したり, シス テムの条件に合わない状況となった場合, スマホ操作時 における覚醒度低下を踏まえると, ドライバが「直ちに そのことを認知して確実に車の操作をできる状況」とは 必ずしも言えないと考えられる。先行研究(15)では, 運転 権限について, クルマからドライバへの権限移譲(TOR: Take Over Request)への対応には「用具の作用」「手の使用」 「覚醒度」「没入度」が影響しており，興味がなく眠気を 催すタスクや，深く思考し集中しすぎるタスクは避ける ベきと述べられている。また,「勉強」「本」「ネット」「ゲ 一ム」では, TOR 時のドライバの反応遅れが,「勉強」

「本」「ネット」では, 自動運転時の眠気が高いことが示 唆されている。

本論の結果を踏まえてこのことを考察する。本論では, スマホを操作している実験協力者は,「ゲーム」や「ネッ ト」をやっていたが,「ネット」は上記先行研究(15)に従え ば,自動運転時の眠気が高いということと整合している。 
「ゲーム」については,「深く思考し集中しすぎるタスク」 であるが，高速道路を自動運転するという単純な状況・ 環境であったため，思考・集中するよりも，むしろ，眠 気の影響の方が強く現れる結果になったものと考えられ る。

今回の実験では, ドライビングシミュレータのシナリ オ設計の都合上, 他車両が存在しない状況下での走行と なっていることもあり，実際の自動運転で走行する環境 に比べて覚醒度の低下や退屈さが著しいと考えられる。 しかし, 先行研究(9)では, 市街地における自動運転走行 時の検証結果であり，他車両が存在する条件下であって も，15[分]の運転で, 覚醒度が増加することが示されて いる。このことから, 仮に他車両が存在したり, 若干道 路形状を変更させたとしても，本論の実験と同様に， ス マホなど運転に関係のない挙動が生じる可能性が示唆さ れ, 先行研究(15)で示されているような, TOR 時の反応遅 れも懸念される。

\section{5.まとめ}

本論では，ドライビングシミュレータを用いた高速道 路環境下運転時におけるドライバ行動について観察し, その結果について考察した。その結果, 自動運転時に, スマホのような，運転に関係のない機器を操作するとい う行動が見られるが，同時に覚醒度低下も見られること がわかった。このことから，スマホ操作を許容するにし ても，自動運転それ自体による覚醒度低下に起因し，ド ライバが「直ちにそのことを認知して確実に車の操作を できる状況」でないことが示唆された。

自動運転に対する依存は，信頼に值するシステムであ れば，当然の行為あるいは判断である(16)が，TORに対応 できるようにする必要がある。本論の内容に沿って言え ば，覚醒度を維持し，TORに対応できるようにする必要 がある。覚醒度を維持する方法として，例えば，香り供 給に伴う低嗅覚刺激(17)や, 視覚刺激による覚醒維持(18)の 事例がある。自動運転の利便性を享受する一方で，TOR に対して適切に対応するためには，今後，このような HMI(Human Machine Interface)を開発し，自動運転レベル 3 においては適切な権限移譲を行うためにこのような HMI を活用することが必要になると考えられる。

謝辞

ドライビングシミュレータ用のキャビンを制作して頂 いた，三咲デザイン合同会社の田島淳氏および小田蛍太 氏にこの場を借りてお礼を申し上げる。

\section{文献}

（1）高度情報通信ネットワーク社会推進戦略本部・官民データ活用推 進戦略会議, 官民 ITS 構想・ロードマップ 2019: https://www.kantei.go.jp/jp/singi/it2/kettei/pdf/20190607/siryou9.pdf （最終アクセス日：2020 年 5 月 18 日）

（2）国土交通省自動車局技術政策課，自動運転を巡る国内・国際動向： http://www.mlit.go.jp/common/001279905.pdf （最終アクセス日 : 2020 年 5 月 18 日)

（3）須田義大, 大口敬, 中野公彦, 大石岳史, 小野晋太郎, 吉田秀範, 杉町敏之：「自動運転システムの社会実装に関する課題と展望」, 生産研究, Vol.68, No.2, pp.95-98, 2016

（4）高度情報通信ネットワーク社会推進戦略本部・官民データ活用推 進戦略会議, 官民 ITS 構想・ロードマップ 2017〜多様な高度自動 運転システムの社会実装に向けて〜：

https://www.kantei.go.jp/jp/singi/it2/kettei/pdf/20170530/roadmap.pdf （最終アクセス日：2020 年 5 月 18 日)

(5) SAE International J3016: "Taxonomy and Definitions for Terms Related to Driving Automation Systems for On-Road Motor Vehicle”, 2016

(6) 劉海龍, 平岡敏洋, 田中誠也：「運転自動化システムに対する過信 発生メカニズムと運転行動過程のモデル化」, 計測自動制御学会シ ステム・情報部門学術講演会 2018 講演論文集, 2018

（7）シンク出版：「改正道路交通法が施行されますー2020 年 4 月 1 日 施行」,

https://www.think-sp.com/2020/03/12/dokoho-kaisei-jido-unten-20203-12/（最終アクセス日：2020 年 5 月 16 日）

（8）荒川俊也：「自動運転への過信・依存の評価を目的としたドライバ 状態の計測と解析」, 知能と情報 (日本知能情報ファジィ学会誌), Vol.32, No.3, pp.98-104, 2020

(9) T. Arakawa, R. Hibi and T. Fujishiro : "Psychophysical assessment of a driver's mental state in autonomous vehicles", Transportation Research Part A: Policy and Practice, Vol. 124, pp.587-610, 2019

（10）内田信行, 浅野陽一, 横谷靖, 植田俊彦, 飯星明:「「意識の脇見」 を伴う対話時における運転者の視覚情報処理」, 自動車技術会論文 集, Vol.39, No.6, pp.6_217-6_222, 2008

(11) T. Arakawa : "Trial Verification of Human Reliance on Autonomous Vehicles from the Viewpoint of Human Factors", International Journal of Innovative Computing, Information and Control, Vol.14, No.2, pp.491-501, 2018

(12) 本間亮平, 若杉貴史, 小高賢二 : 「高度自動運転における権限委譲 方法の基礎的検討 - 自動運転時の覚醒度低下や運転以外の作業 と権限移譲時のドライバ対応行動 -」, 自動車技術会論文集, Vol.47, No.2, pp. 537-542, 2016

(13) J. C. F. de Winter, R. Happee, M. H. Martens, and N. A. Stanton : "Effects of Adaptive Cruise Control and Highly Automated Driving on Workload and Situation Awareness: A Review of the Empirical Evidence", Transportation Research Part F: Traffic Psychology and Behavior, Vol.27, pp. 196-217, 2014

(14) ロボスタ：「【調査】クルマが完全自動運転になったら何をして過 ごしたい?〜若年は「エンタメ」志向、ミドル世代は「睡眠や食 事」, https://robotstart.info/2019/12/09/intage-autonomous.html（最終 アクセス日：2020 年 5 月 20 日) 
（15）阪田万悠子, 小松原明哲：「自動運転車における TOR の対応時 間にサブタスクが与える影響について」, 人間工学, Vol. 55 (Supplement), 2C3-7, 2019

(16) 稲垣敏之：「信頼と権限：ヒトと機械の共創の視点から」, 第 7 回 ITS シンポジウム， 2008

(17) 鈴木桂輔, 佐藤桂, 太田浩司:「運転行動を改善する低嗅覚刺激の 香り供給パターンの最適化」, ヒューマンインタフェース学会論文 誌, Vol.12, No.3, pp.313-322, 2010

（18）星野博之，坂口靖雄：「運転環境に適合したサッカー度誘導視覚刺 激によるドライバ覚醒維持」, 自動車技術会論文集, Vol.47, No,3, pp.759-765, 2016

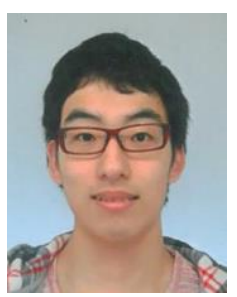

\section{貴答 竣亮}

2020 年 3 月愛知工科大学工学部機械システム工 学科卒業。同年 4 月日産自動車株式会社入社, 現 在に至る。

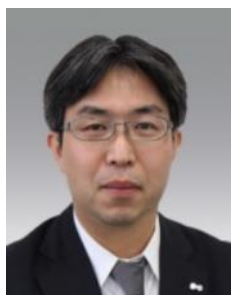

\section{荒川 俊也}

2001 年早稲田大学理工学部機械工学科卒業。 2003 年東京大学大学院総合文化研究科博士前期課 程修了, 2003 年富士重工業(株) (現: (株) SUBARU) 入社。2012 年総合研究大学院大学複合科学研究科 博士後期課程修了, 博士 (学術)。2013 年愛知工科 大学工学部機械システム工学科准教授, 2016 年同 大学同学科教授, 2018 年同大学 ITS 研究所所長兼 任, 2020 年同大学次世代自動車システム研究所所 長兼任。自動運転時のヒューマンファクタ, 地理情 報システムと最適化法のインフラ管理への活用な どに従事。2017 年より政策研究大学院大学政策研 究センター客員研究員, 2020 年より静岡県工業技 術研究所富士工業技術支援センター外部研究員。 